Wykład dr. Nikolasa Nikasa pt. Wokót ksztaltu ustawy o in vitro-wspótczesna medycyna i biotechnologia a nowe kierunki dzialań prawnych, Lublin, 14 kwietnia 2015 r.

14 kwietnia 2015 r. w murach Collegium Iuridicum Katolickiego Uniwersytetu Lubelskiego Jana Pawła II odbył się wykład dr. Nikolasa Nikasa pt. Wokół kształtu ustawy o in vitro - współczesna medycyna $i$ biotechnologia a nowe kierunki działań prawnych. Zaproszony gość to amerykański adwokat $\mathrm{z}$ wieloletnim doświadczeniem, a także szef Bioethics Defense Fund - organizacji pozarządowej skupiającej się na szeroko rozumianej ochronie ludzkiego życia. Uczestniczy w sprawach sądowych dotykających kwestii bioetycznych takich jak: prawo do odmowy dokonania aborcji, asystowane samobójstwo, klonowanie czy badania na ludzkich komórkach macierzystych. W swojej działalności pełnił funkcję konsultanta Prezydenckiej Rady Bioetycznej oraz stawał przed Senatem USA w sprawach dotyczących aborcji i wolności słowa. Podczas swojego wystąpienia w Lublinie opowiedział zgromadzonej publiczności o zagrożeniach, jakie kryją się za procedurą zapłodnienia pozaustrojowego. Spotkanie stanowiło część ogólnopolskiej serii wykładów, które odbyły się w dniach 13-17 kwietnia 2015 r. w uniwersytetach: Jagiellońskim, Warszawskim, im. Adama Mickiewicza w Poznaniu, Wrocławskim oraz w Szkole Głównej Handlowej. Organizatorami lubelskiego spotkania były: Katedra Prawa Wyznaniowego WPPKiA KUL oraz Instytut na rzecz Kultury Prawnej Ordo Iuris.

Zanim rozpoczął się wykład, głos zabrał ks. dr hab. Piotr Stanisz prof. KUL, kierownik Katedry i dziekan Wydziału. W krótkich słowach przywitał dr. Nikasa oraz podkreślił konieczność publicznej debaty nad kwestią zapłodnienia pozaustrojowego, szczególnie w kontekście procedowanego projektu ustawy, mającej regulować metodę in vitro. Podziękował też prelegentowi za poświęcenie w przybliżaniu tej tematyki.

Zaproszony gość swoje rozważania rozpoczął od zwrócenia uwagi na współczesną przypadłość w myśleniu o rozwoju technologicznym jeśli coś jest możliwe do zrobienia, to należy to zrobić. W konsekwencji, bardzo często nie prowadzi się poważnej refleksji nad postępem - czy naprawdę służy on dobru człowieka, czy może w zakamuflowany sposób go niszczy. Mecenas wskazał zapłodnienie in vitro jako przykład takiego braku refleksji. 
Pierwszy zarzut sformułowany przez dr. Nikasa wobec tej procedury to: selekcja, zamrażanie, niszczenie i eksperymentowanie na embrionach, które stanowią ludzkie życie we wczesnej fazie rozwoju. Wszystkie powyższe praktyki mają charakter eugeniczny bądź aborcyjny, a mimo to nie wzbudzają słusznego oburzenia wśród opinii publicznej.

Prelegent zwrócił także uwagę, że kobiety coraz częściej decydują się na dziecko mając ponad trzydzieści czy nawet czterdzieści lat. Następnie przytoczył statystyki dotyczące prawdopodobieństwa urodzenia zdrowego dziecka, poczętego metodą in vitro. Według nich, o ile wśród kobiet poniżej trzydziestego piątego roku życia szansa ta wynosi około $40 \%$, to spada ona drastycznie tuż po przekroczeniu tego progu wiekowego, aż do pułapu $2 \%$ prawdopodobieństwa dla kobiet po czterdziestym roku życia. Skłania to ustabilizowane finansowo kobiety do kupowania komórek jajowych od młodych dawczyń, by zwiększyć szanse na zdrowe urodzenie - przestrzenią takiego handlu jest internet. Uczestnicy spotkania mogli przeczytać fragmenty ogłoszeń sprzedaży komórek, wskazujące na skrajnie przedmiotowe traktowanie życia ludzkiego.

Dalej, Nikolas Nikas wskazał na kolejne konsekwencje swobodnego stosowania metody in vitro, czyli surogację. Jest ona sposobem na uniknięcie ograniczeń związanych z ciążą, a równocześnie ma naturę zwykłej transakcji, co automatycznie sytuuje dziecko jako jej przedmiot. Rzeczywistość pokazuje, że zgodę na bycie surogatką zazwyczaj wyrażają potrzebujące pieniędzy, biedne kobiety z krajów dotkniętych ubóstwem. Stanowi to przykład ekonomicznego, upokarzającego wyzysku. Mecenas ostrzegł też przed nieoczekiwanymi konsekwencjami stosowania metody in vitro, mogącymi pojawić się dopiero po kilkudziesięciu latach od jej upowszechnienia.

Następnie przyszedł czas na pytania z sali. Szczególnie krzepiący był fakt, iż audytorium stanowili głównie młodzi ludzie, w dużej mierze studenci KUL i Uniwersytetu Medycznego w Lublinie. To do nich skierowane zostały słowa dr. Nikasa, zachęcające do głębokiej formacji duchowej i intelektualnej, która w przyszłości pomoże im osiągnąć zawodowe cele i służyć społeczności ludzkiej, jej godności i wolności. Na pytanie, czy wyznawana przez niego religia ma odbicie w prowadzonych przez niego badaniach, zaproszony gość odpowiadając podkreślił, że w swojej pracy nie używa argumentów odwołujących się do jakiejkolwiek religii, choć sam jest człowiekiem wierzącym. Wynika to z jego przekonania o możliwości znalezienia odpowiedniego merytorycznego uzasadnienia 
dla swoich tez $\mathrm{w}$ wiedzy medycznej oraz uniwersalnym porządku naturalnym. Ustosunkowując się do komentarza jednej z osób na temat kształtu prawnych regulacji metody in vitro przyznał, że najlepszym rozwiązaniem byłby absolutny zakaz jej stosowania. Nie pozwalałby on na relatywizowanie nieetyczności tego typu zapłodnienia pozaustrojowego w dalszych latach i całkowicie chroniłby godność życia ludzkiego.

Po półtoragodzinnym wykładzie Nikolas Nikas podziękował wszystkim uczestnikom za uwagę, a władzom Wydziału za gościnę, ufając, że nie była to jego ostatnia wizyta w Lublinie.

Mgr Kacper Chołody Wydziat Prawa, Prawa Kanonicznego i Administracji Katolicki Uniwersytet Lubelski Jana Pawła II

\section{Ogólnopolskie Sympozjum Prawa Wyznaniowego pt. Wolność sumienia i religii a bezpieczeństwo i porzadek publiczny, Zabuże, 14-16 września 2015 r.}

W dniach 14-16 września 2015 r. w Zabużu (woj. mazowieckie) odbyło się XII Ogólnopolskie Sympozjum Prawa Wyznaniowego połączone ze Zjazdem Katedr, Zakładów i Wykładowców Prawa Wyznaniowego. Tematem tego Sympozjum była: Wolność sumienia $i$ religii a bezpieczeństwo i porzadek publiczny. Organizatorami Sympozjum byli Instytut Administracji, Samorządu i Prawa, Uniwersytetu Przyrodniczo-Humanistycznego w Siedlcach oraz Polskie Towarzystwo Prawa Wyznaniowego.

Sympozjum otworzył Prezes Polskiego Towarzystwa Prawa Wyznaniowego prof. dr hab. Tadeusz J. Zieliński (ChAT), który wyraził radość z kolejnego, już dwunastego spotkania. Podkreślił istotę prawa wyznaniowego w obliczu kryzysu imigracyjnego oraz jego wpływ na pluralizm światopoglądowy. Następnie głos zabrał dr Józef Różański, Dyrektor Departamentu Wyznań Religijnych oraz Mniejszości Narodowych i Etnicznych Ministerstwa Administracji i Cyfryzacji, który podziękował za pamięć o ministerstwie, przy okazji organizacji kolejnych konferencji z dziedziny prawa wyznaniowego. Podziękował również za wkład teoretyków prawa wyznaniowego w prace ministerstwa. Na zakończenie głos 